\title{
Self-regulatory Efficacy as Potential Moderator on the Relationship Between Organisational Formal Controls, Perceived Group Norms and Workplace Deviance : A Proposed Framework
}

\author{
Kabiru Maitama Kuraa*, Faridahwati Mohd. Shamsudina, Ajay Chauhan ${ }^{a}$ \\ ${ }^{a}$ Othman Yeop Abdullah Graduate School of Business, Universiti Utara Malaysia, 06010 Sintok, Kedah, Malaysia \\ *Corresponding author: km_kura@yahoo.co.uk
}

Article history

Received :4 April 2013

Received in revised form :

25 July 2013

Accepted :15 October 2013

\begin{abstract}
Several factors have been suggested to explain why employees engage in deviant behaviour at the workplace. To date, some of the factors that have been considered include perceived organisational politics perceived organizational justice, organizational trust, group cohesiveness and group identity, among others. Despite these studies, however, few studies have attempted to consider the influence of organisational formal controls and perceived group norms on workplace deviance. Even if any, they have reported conflicting findings. Therefore, a moderating variable is suggested. This paper proposes selfregulatory efficacy as potential moderator on the relationship between organisational formal controls, perceived group norms and workplace deviance.
\end{abstract}

Keywords: Workplace deviance; formal control; perceived group norm; conceptual framework

(C) 2013 Penerbit UTM Press. All rights reserved

\subsection{INTRODUCTION}

Workplace deviant behaviour is defined as a voluntary behaviour engaged by employee that is contrary to the significant organizational norms and it is considered as a threat to the wellbeing of an organization and/or its members (Robinson \& Bennett, 1995). Workplace deviance is pervasive phenomenon and costly to organisations (Aquino, Galperin, \& Bennett, 2004; Lawrence \& Robinson, 2007). For example, Zogby International (ZI), a leading polling firm in the United States was commissioned by the Workplace Bullying Institute (WBI) to conduct an online survey on workplace bullying involving 4,210 adult Americans. One of the key findings from the survey was that in 2010, 35\% of adult Americans experienced workplace bullying (WBI, 2010). In another related survey, employee theft was reported to be attributed to about $45 \%$ of the U.S. retailers' inventory shortage in the year 2010 (Hollinger \& Adams, 2010). Workplace deviant behaviour was also found to be negatively related to both corporate profitability and customer satisfaction (Detert, Treviño, Burris, \& Andiappan, 2007). Thus, workplace deviant behaviour is costly to organisation and its stakeholders.

Several factors have been suggested to explain why employees engage in deviant behaviour at the workplace. One of the key determinants of employee deviant behaviour is related to the organization. According to Robbins and Judge (2010), organizational factors are an important consideration in understanding employee attitude and behaviour at work because they are able to shape the way employees think, feel, and behave.
To date, some of the organizational-related factors that have been considered include perceived organizational justice (Ambrose, Seabright, \& Schminke, 2002; Devonish \& Greenidge, 2010), organizational trust (Elangovan \& Shapiro, 1998; Thau, Crossley, Bennett, \& Sczesny, 2007), job stress (Fox, Spector, \& Miles, 2001; Penney \& Spector, 2005) and perceived organizational support (Eisenberger, Huntington, Hutchison, \& Sowa, 1986; Ferris, Brown, \& Heller, 2009), among others. In general, these studies found that unfavourable work environment as reflected by injustice at the workplace, poor leadership, job stress, breach of trust and lack of organisational support, for example, are likely to have a significant influence on workplace deviant behaviours (WDBs).

Despite the aforementioned empirical studies on the role of organizational system and process in shaping employee behaviour at work, literatures indicate that less attention has been paid to the influence of organizational formal control on workplace deviance. Even if there are studies on control and workplace deviant behaviour, the studies were limited to examining specific types of workplace deviant behaviours such as employee absenteeism and theft at the workplace. But, in reality, employees engage in various types of deviant behaviour at work (Bennett \& Robinson, 2000; Hollinger \& Clark, 1982). Considering specific types of workplace deviant behaviours will not allow better understanding of the variety of deviant behaviours employees engage in at work. Additionally, organizational formal control is considered in the present study because it could be a potentially important factor in shaping employee behaviour (Hollinger \& Clark, 1982). 
In addition to organisational formal control, perceived group norm is another important predictor of employee behaviour. A group norm is defined as established rules that determine acceptable and unacceptable behaviour in a group (Levi, 2011). Workgroup norms perform regulatory and survival functions; for these reasons alone they have strong influence on employee behaviour (Parks, 2004). Previous studies have generally revealed that a group norm is associated with organizational citizenship behaviour (Ehrhart \& Naumann, 2004; Moorman \& Blakely, 1995), group performance (Gellatly, 1995; Janicik \& Bartel, 2003; $\mathrm{Ng} \&$ Van Dyne, 2005), and organisational performance (Cai \& Yang, 2008; Langerak, 2001) among others. Despite the theoretical and empirical efforts to understand the influence of work group norms on employee performance, there is a paucity of studies on the influence of work group norms on workplace deviance, with some exceptions of the works of Dabney (1995) and Bamberger and Biron (2007). The present paper will be significantly different from these two studies because the later mainly focused on specific forms of deviant behviour at work (i.e. drug diversion and employee absenteeism) respectively. Hence, further studies incorporating a broader form of workplace deviant behaviour construct (Robinson \& Bennett, 1995) are needed. As argued by Parks (2004), as work group norms have bearing on employee positive behaviour, it is expected that they also have influence on employee negative behaviour. The present paper aims to fill these gaps in the existing organisational behaviour literature.

\subsection{WORKPLACE DEVIANCE}

Although deviant behaviour construct has gained a lot of momentum for several decades now, however, the reviews of the literature indicated that there is lack of agreement regarding not only the terminology used, but also the definition offered what is considered to be a similar construct(Robinson \& Bennett, 1997; Shamsudin, 2006). For example, researchers have assigned different names to the deviant behaviour construct such as "Organizational misbehaviour", "counterproductive work behaviour" "dysfunctional behaviour" and "non-complaint behaviour" among others. Although different terminologies are used, using different theoretical perspectives, organizational behaviour researchers apparently agree that such behaviour could bring harm to both individual and organization (Shamsudin, Chauhan, \& Kura). Hence, in the present study, Robinson and Bennett's (1995) definition of workplace deviant behaviours is recognized as the working definition of the construct WDB. Researchers have indicated that workplace deviant behaviour is potentially destructive or harmful to both organization and its members (Lawrence \& Robinson, 2007; Spector \& Fox, 2002).

\subsection{ORGANIZATIONAL FORMAL CONTROL}

Numerous definitions of organizational formal control can be found in the literature. However, these definitions have taken at least three different perspectives including marketing perspective, accounting perspective and human resource management perspective. From the marketing perspective, formal control is defined by Jaworski(1988) as a series of activities designed to ensure that specified plans are well implemented and desired outcomes are actually achieved. From the accounting perspective, Merchant (1998) defined organisational formal control as "all the devices managers use to ensure that the behaviours and decisions of people in the organization are consistent with the organization's objectives and strategies" (p.2). From the human resource management perspective, formal control refers to mechanisms put in place by management such as rules and regulations, disciplinary measures and auditing with the aim of monitoring, detecting, punishing and minimizing the occurrence of improper conduct (Vardi \& Weitz, 2004). While other perspectives of organizational formal control are equally important, however his study adopts human resource management perspective because the focus of this paper study is on human resource management practices.

\subsection{Organizational Formal Control And Workplace Deviance}

Empirical support for the relationship between organizational formal control and workplace deviant behaviour is limited. Specifically, some of these studies focused on a single component of formal control as the predictor of workplace deviant behaviours, while some other studies focused on multiple components of formal control as the antecedents of workplace deviant behaviours (Bello \& Gilliland, 1997; Challagalla \& Shervani, 1996; Chi-Ko, Wing Tung, \& Ho, 2005; Evans, Landry, Po-Chien, \& Shaoming, 2007; Fang, Evans, \& Zou, 2005; Flamholtz, Das, \& Tsui, 1985; Khakwani, Aslam, Ashraf, Javad, \& Shabbir, 2012; Miao \& Evans, 2012; Niehoff \& Paul, 2000; Wang, Dou, \& Zhou, 2012).

Additionally, most of the few existing studies that have been conducted the relationship between organizational formal control and workplace deviant behaviour have considered specific types of WDB and their results were conflicting. For example, de Lara, Tacoronte, and Ding (2006) used Structural Equation Modeling (SEM) to investigate the relationship between formal control strategies and cyberloafing among 758 non-teaching staff from public university in Spain. The path diagram for the hypothesized model indicated that perceived organizational control was negatively related to cyberloafing (i.e. when employee perceived that management exercises strong control over organizational activities, he is less likely to engage in cyberloafing, defined as personal use of internet services by employees during work hours).

In another study Hollinger and Clark (1982) adopted a crosssectional research design to examine the effects of formal management sanctions, along with informal co-workers' sanctions on workplace deviance among 9,175 employees from 47 different organizations in United States. The standardized regression coefficients and path analysis showed that perceptions of formal management sanctions was negatively related to deviant behaviour, defined as employee theft. In a related studies, Detert, Treviño, Burris, and Andiappan (2007) and Vardi and Weitz (2001) found that process controls have significant inverse relationship with workplace deviance. On the other hand process control in form of supervisory guidance was not found to be significant predictors of deviant behaviour (Dineen, Lewicki, \& Tomlinson, 2006).

In another study, Parilla, Hollinger and Clark (Parilla, Hollinger, \& Clark, 1988) employed triangulation approach to examine the effects of organisational control on deviant behaviour. The data for the study were collected from 47 different formal work organisations in United States. The results of quantitative study showed that organisational control in retail industry has significant negative association with employee theft. In a similar vein, Robertson and Anderson (1993) extended research on workplace deviance by investigating the effects of control system on sales task environment on behaviour among 487 industrial field salespeople in United States. The study employed projective vignettes and sales scenarios in order to elicit candid response from the respondents. The results found no significant relationship between sales force control (i.e. a process 
of monitoring, supervising and compensating employee) and ethical behaviour.

Taken together, while the above studies have made substantial contributions to the organizational behaviour literature by empirically demonstrating the influence of organizational formal controls on various work-related attitudes and behaviours, however, it is important to note that the findings of these studies were mixed. Furthermore, several reasons may account for these conflicting findings. Hence, this suggests introducing a potential moderator towards better understanding the relationship between organizational formal controls and workplace deviance. Furthermore, as we noted earlier in chapter one of the present study, apart from organizational formal control, perceived group norm is another important factor that has been studied by organizational researchers and practitioners alike because of its significance role in determining employee behaviour. However, due to mixed results, the present study proposes the following:

Proposition 1: Organizational formal control will be negatively associated with workplace deviance.

\subsection{PERCEIVED GROUP NORMS}

Every group develops norms; some conventions, habits, customs and/or expectations that regulate the behaviour of its members (Parks, 2004). A group norm is defined as established rules that determine acceptable and unacceptable behaviour in a group (Levi, 2011). This definition implies that, workgroup norms perform regulatory and survival functions; for these reasons alone they have strong influence on employee behaviour (Parks, 2004).

\subsection{Perceived Group Norms And Workplace Deviance}

Several studies have been conducted on the perception of group norms in different orgnisational settings. Furthermore, although there is abundant empirical research linking the perception of group norms with workplace deviant behaviour, however, the findings of these studies is mixed. Hence, this suggests that further studies are needed to better understand this relationship. Meanwhile, some of the many empirical studies on perceived group norms - workplace deviance relationship include the study conducted by Elek, Miller-Day and Hecht (2006), which examined the effects of group norms on adolescent use of substance. Four thousand, two hundred and thirty four $(4,234)$ students agreed to be included in the study. The findings of the study revealed that group norms (i.e. descriptive and injunctive norms) have strongest significant effect on adolescent use of substance.

Similarly, Väänänen, Tordera, Kivimäki, Kouvonen, Pentti, Linna, and Vahtera (2008), the examined the effect of injunctive norms on sickness absence behaviour. The result of the study revealed that perceptions of work group members' permissive absence norms did not have effect on sickness absence behaviour. Kivlighan, Kivlighan and Cole (2012) also conducted a study to examine the interaction effect of commitment on the relationship between group members' absence norm and group member's absence for the next academic session. The study found that frequency of other group members absence is significant predictor of group member absence in the next academic session. In another study, Smith and McSweeney (2007) investigated the influence of attitudes, group norms, perception of behavioural control and past behaviour on donating intentions and behaviour. The study found that attitudes, perceived behavioural control, injunctive norms, moral norms and past behaviour are significant predictors of donating intentions to charitable organisations. However, descriptive norm was not found to be a significant predictor of donating intentions to charitable organisations. Hence, the following proposition is offered:

Proposition 2: Perceived group norms will be positively associated with workplace deviance.

\subsection{SELF-REGULATORY EFFICACY}

Organizational and social psychology literature revealed a large number of studies that have been conducted on the influence of self-regulatory efficacy on various attitudinal and behavioural outcomes such as academic achievement, health-related behaviours and work-related performance, among others (Bandura, Caprara, Barbaranelli, Gerbino, \& Pastorelli, 2003; Caprara, Regalia, \& Bandura, 2002; Caprara et al., 1998; Caprara \& Steca, 2005; Kelly, Zyzanski, \& Alemagno, 1991; Strecher, McEvoy DeVellis, Becker, \& Rosenstock, 1986). Self-regulatory efficacy is defined as individual's belief in their capacity to regulate and control thoughts, feelings, motivation and behaviour for attaining of goals(Bandura, 1986, 1993; Zimmerman, Bandura, \& Martinez-Pons, 1992).

According to control theory (Flamholtz, et al., 1985; Jaworski, 1988; Ouchi, 1979; Snell, 1992), formal control instituted by an organization should theoretically able to regulate employee behaviour at work through discipline and punishment. Similarly, according to social learning control theory, group norms established by members of an organisation should also be theoretically able to regulate the behaviour of individual members of an organisation. However, empirical results on the effects of formal control on employee behaviours particularly in reducing deviant behaviour at work appear mixed. For example, Hollinger and Clark (1982), and Chi-Ko, Wing-Tung \&Ho (2005) demonstrated a significant negative relationship between formal control, defined as supervisor's reactions towards employees' deviant behaviours and workplace deviance. Similarly, Evans, Landry, Li and Zou (2007), reported a significant association between input control, defined as method of imparting skills needed for the job and job-related outcomes. Conversely, Fagbohungbe, Akinbode and Ayodeji (2012) investigated the relationship between perceived control environment and workplace deviance. They found no significant relationship. Similarly, Robertson and Anderson (1993), who examined the effects of control system and sales task environment on behaviours, found that sales force control is not a significant predictor of ethical behaviour.

Furthermore, empirical results on the relationship between perception of group norms and workplace deviant behaviour appear mixed. For example, Elek, Miller-Day and Hecht (2006), which examined the effects of group norms on adolescent use of substance. Four thousand, two hundred and thirty four students agreed to be included in the study. The findings of the study revealed that group norms (i.e. descriptive and injunctive norms) have strongest significant effect on adolescent use of substance.

Similarly, Väänänen, Tordera, Kivimäki, Kouvonen, Pentti, Linna, and Vahtera (2008), the examined the effect of injunctive norms on sickness absence behaviour. The result of the study revealed that perceptions of work group members' permissive absence norms did not have effect on sickness absence behaviour. Kivlighan, Kivlighan and Cole (2012) also conducted a study to examine the interaction effect of commitment on the relationship between group members' absence norm and group member's absence for the next academic session. The study found that frequency of other group members absence is significant predictor of group member absence in the next academic session. 
Frone and Brown (2010) extended research on workplace deviance by conducting a study to investigate the influence of perceived group norms (i.e. descriptive norms and injunctive norms) on workplace substance use among 2,829 public service employees in United States. As predicted, the results of the study revealed that both perceived injunctive norms and perceived descriptive norms were significant predictors of substance use. Gellatly (1995) also conducted a study to examine the influence of perceived absence norm on individual and group level absenteeism among 425 employees of hospital and food services in Canada. The study used objective measures of employee absenteeism, which was operationalized as the frequency of absence and total days absent. These objective data were obtained from the records office of each organisation. The results showed that perceived absence norm was positively related to both individual and group level absenteeism

On the basis of the mixed findings reported in the previous studies, the present study will incorporate self-regulatory efficacy as a potential moderator on the influence of organizational formal controls and perceived group norms on workplace deviance. This is in line with Baron and Kenny's (1986) assertion that a moderator variable is usually incorporated when the relationship between a predictor and a criterion variable is found to be unexpectedly weak or inconsistent. Jaworski (1988) strongly argued that the effectiveness of various control mechanisms may be contingent upon internal and external contingency variables. Hence, this suggests the need for a moderator variable. Therefore, in order to better understand the influence of organizational formal controls and perceived group norms on workplace deviance, this study suggests that self-regulatory efficacy might moderate the relationships.

Previous studies have examined the moderating role of selfefficacy on the relationship between scholastic aptitude and persistence in academic performance(Brown, Lent, \& Larkin, 1989), transformational leadership and work-related attitudes (Walumbwa, Lawler, Avolio, Peng, \& Kan, 2005), transformational leadership and job performance(Walumbwa, Avolio, \& Zhu, 2008) and exposure to workplace bullying health complaints (Gemzøe-Mikkelsen \& Einarsen, 2002). Generally, the findings of these studies supported the notion that self-efficacy can override the tendency of employee to exhibit negative workrelated attitudes and behaviours. Yet, despite the substantial evidence that self-regulatory efficacy in override the tendency of employee to engage in deviant behaviour, researchers still do not adequately understand moderating role of self-regulatory efficacy on the effects of orgnisational formal controls and perceived group norms on workplace deviance.

Bandura's (1986) self-efficacy theory may provide insight into the moderating role of self-regulatory efficacy on the effects of formal controls and perceived group norms on workplace deviance. Self-efficacy theory postulates that all aspects of human life such as health activities, academic activities and job related activities are influenced by perceived self-efficacy. The stronger individual's self-efficacy beliefs to resist peer pressure the less likely he or she will engage in deviant behaviours. From managerial perspective, it can be argued that organisational formal control and perceived group norms alone are not sufficient to reduce the occurrence of deviant behaviour in the workplace because, according to Ackroyd and Thompson (1999), individuals are creative people who will likely find ways on how to beat the formal system. Hence, the following proposition is offered:

Proposition 3: Self-control will moderate the relationship between orgnisational formal controls, perceived group norms and workplace deviance.

\subsection{PROPOSED RESEARCH FRAMEWORK}

Based on the above empirical evidences, a proposed research framework for this study illustrating the moderating role of selfregulatory efficacy on the influence of organisational formal controls and perceived group norms on workplace deviance is depicted in Figure 1.

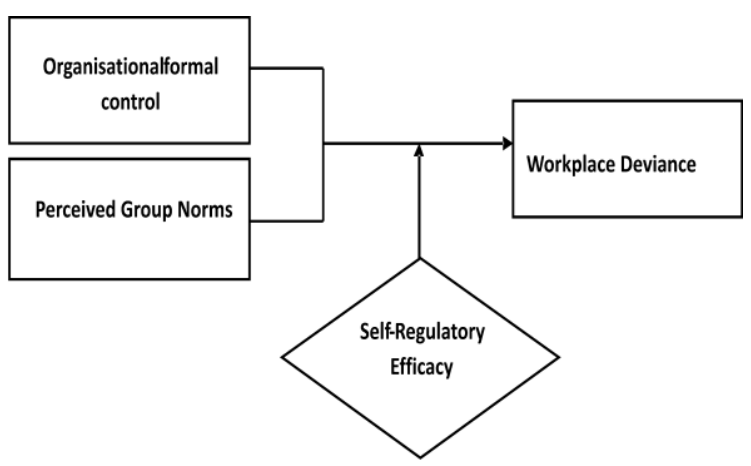

Figure 1 Research framework

In explaining the moderating role of self-regulatory efficacy on the relationship between organisational formal controls, perceived group norms and workplace deviance, the present paper proposes that that the extent to which organisational formal controls and perceived group norms influences employee to engage in deviant behaviour vary, depending upon the level of individual self-regulatory efficacy. The stronger individual's selfefficacy beliefs to resist peer pressure the less likely he or she will engage in workplace deviant behaviours. Given the empirical support for the self- efficacy theory across various organizational settings, it is proposed that this theory would provided an empirical support for the moderating role of self-regulatory efficacy on the influence of organisational formal controls and perceived group norms on deviant behaviour in the workplace.

\subsection{CONCLUSION}

This paper has proposed the moderating role of self-regulatory efficacy on the relationship between organisational formal controls, perceived group norms and workplace deviance as depicted in Figure 1. If the proposed framework is validated, the finding will provide important insight to managers and practitioners into the significant role of formal controls, perceived group norms and self-regulatory efficacy, in reducing deviant behaviour at work.

\section{References}

[1] Ackroyd, S. \& Thompson, P. 1999. Organizational Misbehaviour London: Sage Publications Ltd.

[2] Akins, C. K. 2004. The Role of Pavlovian conditioning in Sexual Behavior: A Comparative Analysis of Human and Nonhuman Animals. International Journal of Comparative Psychology. 17(2).

[3] Ambrose, M. L., Seabright, M. A., \& Schminke, M. 2002. Sabotage in the Workplace: The Role of Organizational Injustice. Organizational Behavior and Human Decision Processes. 89: 947-965. doi: 10.1016/s0749-5978(02)00037-7.

[4] Aquino, K., Galperin, B. L., \& Bennett, R. J. 2004. Social Status and Aggressiveness as Moderators of the Relationship Between Interactional 
Justice and Workplace Deviance. Journal of Applied Social Psychology. 34: 1001-1029. doi: doi: 10.1111/j.1559-1816.2004.tb02581.x.

[5] Bamberger, P. \& Biron, M. 2007. Group Norms and Excessive Absenteeism: The Role of Peer Referent Others. Organizational Behavior and Human Decision Processes. 103: 179-196. doi 10.1016/j.obhdp.2007.03.003.

[6] Bandura, A. 1986. The Explanatory and Predictive Scope of Self-Efficacy Theory. Journal of Social and Clinical Psychology. 4: 359-373.

[7] Bandura, A. 1993. Perceived Self-Efficacy in Cognitive Development and Functioning. Educational Psychologist. 28(2): 117-148. doi: 10.1207/s15326985ep2802_3.

[8] Bandura, A., Caprara, G. V., Barbaranelli, C., Gerbino, M., \& Pastorelli, C. 2003. Role of Affective Self-Regulatory Efficacy in Diverse Spheres of Psychosocial Functioning. Child Development. 74: 769-782.

[9] Baron, R. M., \& Kenny, D. A. 1986. The Moderator-Mediator Variable Distinction in Social Psychological Research: Conceptual, Strategic, and Statistical Considerations. Journal of Personality and Social Psychology. 51: 1173-1182. doi: 10.1037/0022-3514.51.6.1173.

[10] Bello, D. C., \& Gilliland, D. I. 1997. The Effect of Output Controls, Process Controls, and Flexibility on Export Channel Performance. The Journal of Marketing. 22-38.

[11] Bennett, R. J., \& Robinson, S. L. 2000. Development of a Measure of Workplace Deviance. Journal of Applied Psychology. 85: 349-360. doi: 10.1037/0021-9010.85.3.349.

[12] Brown, S. D., Lent, R. W., \& Larkin, K. C. 1989. Self-efficacy as a Moderator of Scholastic Aptitude-Academic Performance Relationships. Journal of Vocational Behavior. 35(1): 64-75. doi: 10.1016/00018791(89)90048-1.

[13] Cai, S., \& Yang, Z. 2008. Development of Cooperative Norms in the Buyer-Supplier Relationship: The Chinese Experience. Journal of Supply Chain Management. 44(1): 55-70. doi: 10.1111/j.1745493X.2008.00045.x.

[14] Caprara, G. V., Regalia, C., \& Bandura, A. 2002. Longitudinal Impact of Perceived Self-Regulatory Efficacy on Violent Conduct. European Psychologist. 7(1): 63-69. doi: 10.1027//1016-9040.7.1.63.

[15] Caprara, G. V., Scabini, E., Barbaranelli, C., Pastorelli, C., Regalia, C., \& Bandura, A. 1998. Impact of Adolescents' Perceived Self-Regulatory Efficacy on Familial Communication and Antisocial Conduct. European Psychologist. 3: 125-132. doi: 10.1027//1016-9040.3.2.125.

[16] Caprara, G. V., \& Steca, P. 2005. Affective and Social Self-Regulatory Efficacy Beliefs as Determinants of Positive Thinking and Happiness European Psychologist. 10: 275-286. doi: 10.1027/1016-9040.10.4.275.

[17] Challagalla, G. N., \& Shervani, T. A. 1996. Dimensions and Types of Supervisory Control: Effects on Salesperson Performance and Satisfaction. The Journal of Marketing. 89-105.

[18] Chi-Ko, K., Wing Tung, A., \& Ho, J. M. C. 2005. Normative Controls and Self-Reported Counterproductive Behaviors in the Workplace in China. Applied Psychology: An International Review. 54: 456-475. doi: 10.1111/j.1464-0597.2005.00220.x.

[19] Dabney, D. 1995. Workplace Deviance Among Nurses: The Influence of Work Group Norms on Drug Diversion and/or Use. Journal of Nursing Administration. 25(3): 48-55.

[20] de Lara, P. Z. M., Tacoronte, D. V., \& Ding, J. M. T. 2006. Do Current Anti-cyberloafing Disciplinary Practices Have a Replica in Research Findings?: A Study of the Effects of Coercive Strategies on Workplace Internet Misuse. Internet Research. 16: 450-467.

[21] Detert, J. R., Treviño, L. K., Burris, E. R., \& Andiappan, M. 2007. Managerial Modes of Influence and Counterproductivity in Organizations: A Longitudinal Business-Unit-Level Investigation. Journal of Applied Psychology. 92: 993-1005 doi: 10.1037/00219010.92.4.993.

[22] Devonish, D., \& Greenidge, D. 2010. The Effect of Organizational Justice on Contextual Performance, Counterproductive Work Behaviors, and Task Performance: Investigating the Moderating Role of AbilityBased Emotional Intelligence. International Journal of Selection and Assessment. 18: 75-86. doi: 10.1111/j.1468-2389.2010.00490.x.

[23] Dineen, B. R., Lewicki, R. J., \& Tomlinson, E. C. 2006. Supervisory guidance and behavioral integrity: Relationships with employee citizenship and deviant behavior. Journal of Applied Psychology, 91, 622-635. doi: 10.1037/0021-9010.91.3.622

[24] Eder, P., \& Eisenberger, R. 2008. Perceived organizational support: Reducing the negative influence of coworker withdrawal behavior. Journal of Management, 34(1), 55-68.

[25] Ehrhart, M. G., \& Naumann, S. E. 2004. Organizational Citizenship Behavior in Work Groups: A Group Norms Approach. Journal of Applied Psychology, 89, 960-974. doi: 10.1037/0021-9010.89.6.960

[26] Eisenberger, R., Huntington, R., Hutchison, S., \& Sowa, D. 1986. Perceived organizational support. Journal of Applied Psychology, 71, 500-507. doi: 10.1037/0021-9010.71.3.500
[27] Elangovan, A. R., \& Shapiro, D. L. 1998. Betrayal of Trust in Organizations. The Academy of Management Review, 23(3), 547-566.

[28] Elek, E., Miller-Day, M., \& Hecht, M. L. 2006. Influences of personal, injunctive, and descriptive norms on early adolescent substance use. Journal of Drug Issues, 36(147-171). doi: 10.1177/002204260603600107

[29] Evans, K. R., Landry, T. D., Po-Chien, L., \& Shaoming, Z. 2007. How sales controls affect job-related outcomes: the role of organizational sales-related psychological climate perceptions. Journal of the Academy of Marketing Science, 35, 445-459.

[30] Fang, E., Evans, K. R., \& Zou, S. 2005. The moderating effect of goalsetting characteristics on the sales control systems-job performance relationship. Journal of Business Research, 58, 1214-1222.

[31] Ferris, D. L., Brown, D. J., \& Heller, D. 2009. Organizational Supports and Organizational Deviance: The Mediating Role of Organization-based Self-esteem. Organizational Behavior and Human Decision Processes. 108: 279-286. doi: 10.1016/j.obhdp.2008.09.001.

[32] Flamholtz, E. G., Das, T., \& Tsui, A. S. 1985. Toward an Integrative Framework of Organizational Control. Accounting, Organizations and Society. 10(1): 35-50.

[33] Fox, S., Spector, P. E., \& Miles, D. 2001. Counterproductive Work Behaviour (CWB) in Response to Job Stressors and Organizational Justice: Some Mediator and Moderator Tests for Autonomy and Emotions. Journal of Vocational Behavior. 59: 291-309. doi: 10.1006/jvbe.2001.1803.

[34] Frone, M. R., \& Brown, A. L. 2010. Workplace Substance-Use Norms as Predictors of Employee Substance Use and Impairment: A Survey of US Workers. Journal of Studies on Alcohol and Drugs. 71: 526-534.

[35] Gellatly, I. R. 1995. Individual and Group Determinants of Employee Absenteeism: Test of a Causal Model. Journal of Organizational Behavior. 16: 469-485. doi: doi: 10.1002/job.4030160507.

[36] Gemzøe Mikkelsen, E., \& Einarsen, S. 2002. Relationships between Exposure to Bullying at Work and Psychological and Psychosomatic Health Complaints: The Role of State Negative Affectivity and Generalized Self-Efficacy. Scandinavian Journal of Psychology. 43: 397-405. doi: 10.1111/1467-9450.00307.

[37] Hollinger, R. C., \& Adams, A. 2010. National Retail Security Survey.

[38] Hollinger, R. C., \& Clark, J. P. 1982. Formal and Informal Social Controls of Employee Deviance. The Sociological Quarterly. 23: 333343.

[39] Janicik, G. A., \& Bartel, C. A. 2003. Talking about Time: Effects of Temporal Planning and Time Awareness Norms on Group Coordination and Performance. Group Dynamics: Theory, Research, and Practice. 7(2): 122-134. doi: 10.1037/1089-2699.7.2.122.

[40] Jaworski, B. J. 1988. Toward a Theory of Marketing Control: Environmental Context, Control Types, and Consequences. The Journal of Marketing. 52: 23-39.

[41] Kelly, R. B., Zyzanski, S. J., \& Alemagno, S. A. 1991. Prediction of Motivation and Behaviour Change Following Health Promotion: Role of Health Beliefs, Social Support, and Self-Efficacy. Social Science \&amp; Medicine. 32: 311-320. doi: 10.1016/0277-9536(91)90109-p.

[42] Khakwani, S., Aslam, H. D., Ashraf, F., Javad, T., \& Shabbir, F. 2012 Role of Control Modes in Improving Performance: An Essential Facet for Managing Human Resources. Journal of Educational and Social Research. 2: 241-248.

[43] Kivlighan, D. M., Jr., Kivlighan, D. M., III, \& Cole, O. D. 2012. The Group's Absence Norm and Commitment to the Group as Predictors of Group Member Absence in the Next Session: An Actor-Partner Analysis. Journal of Counseling Psychology. 59(1): 41-49. doi: 10.1037/a0025506.

[44] Langerak, F. 2001. Effects of Market Orientation on the Behaviors of Salespersons and Purchasers, Channel Relationships, and Performance of Manufacturers. International Journal of Research in Marketing. 18: 221234. doi: $10.1300 / J 033 v 08 n 02$

[45] Lawrence, T. B., \& Robinson, S. L. 2007. Ain't Misbehavin: Workplace Deviance as Organizational Resistance. Journal of Management. 33: 378-394. doi: 10.1177/0149206307300816.

[46] Levi, D. 2011. Group Dynamics for Teams. 3rd ed. Thousand Oaks, CA: Sage Publications.

[47] Merchant, K. A. 1998. Modern Management Control Systems: Text and Cases. New Jersey: Prentice-Hall.

[48] Miao, C. F., \& Evans, K. R. 2012. Effects of Formal Sales Control Systems: A Combinatory Perspective. International Journal of Research in Marketing.

[49] Moorman, R. H., \& Blakely, G. L. 1995. Individualism-collectivism as an Individual Difference Predictor of Organizational Citizenship Behavior. Journal of Organizational Behavior. 16(2): 127-142. doi 10.1002/job.4030160204

[50] Ng, K. Y., \& Van Dyne, L. 2005. Antecedents and Performance Consequences of Helping Behavior in Work Groups. Group \& 
Organization $\quad$ Management. $\quad 30: \quad 514-540 . \quad$ doi 10.1177/1059601104269107.

[51] Niehoff, B. P., \& Paul, R. J. 2000. Causes of Employee Theft and Strategies that HR Managers Can Use for Prevention. Human Resource Management. 39(1): 51-64.

[52] Ouchi, W. G. 1979. A Conceptual Framework for the Design of Organizational Control Mechanisms. Management Science. 833-848.

[53] Parilla, P. F., Hollinger, R. C., \& Clark, J. P. 1988. Organizational Control of Deviant Behavior: The Case of Employee Theft. Social Science Quarterly. 69: 261-280.

[54] Parks, C. D. 2004. Group norms. In J. M. Burns, G. R. Goethals \& G. J. Sorenson (Eds.). Encyclopedia of Leadership. Thousand Oaks, CA: Sage Publications. 627-630.

[55] Penney, L. M., \& Spector, P. E. 2005. Job Stress, Incivility, and Counterproductive Work Behaviour (CWB): The Moderating Role of Negative Affectivity. Journal of Organizational Behavior. 26: 777-796. doi: 10.1002/job.336.

[56] Robbins, S. P., \& Judge, T. A. 2010. Organizational Behaviour. 14 ed. New York: Prentice Hall.

[57] Robinson, S. L., \& Bennett, R. J. 1995. A Typology of Deviant Workplace Behaviors: A Multidimensional Scaling Study. Academy of Management Journal. 38: 555-572.

[58] Robinson, S. L., \& Bennett, R. J. 1997. Workplace deviance: Its definition, its manifestations, and its causes. Research on Negotiations in Organizations, 6, 3-27.

[59] Shamsudin, F. M. 2006. Organisational Misbehaviour. Akademika. 69: 57-82.

[60] Shamsudin, F. M., Chauhan, A., \& Kura, K. M. 2012. Self-control as Moderator of the Relationship Between Formal Control and Workplace Deviance: A Proposed Framework. Australian Journal of Business and Management Research. 2(6): Forth-coming.

[61] Smith, J. R., \& McSweeney, A. 2007. Charitable Giving: The Effectiveness of a Revised Theory of Planned Behaviour Model in Predicting Donating Intentions and Behaviour. Journal of Community \& Applied Social Psychology. 17: 363-386. doi: 10.1002/casp.906.

62] Snell, S. A. 1992. Control Theory in Strategic Human Resource Management: The Mediating Effect of Administrative Information. Academy of Management Journal. 35: 292-327.
[63] Spector, P. E., \& Fox, S. 2002. An Emotion-Centered Model of Voluntary Work Behaviour - Some Parallels Between Counterproductive Work Behaviour and Organizational Citizenship Behaviour. Human Resource Management Review. 12: 269-292. doi: 10.1016/s1053 4822(02)00049-9.

[64] Strecher, V. J., McEvoy DeVellis, B., Becker, M. H., \& Rosenstock, I. M. 1986. The Role of Self-Efficacy in Achieving Health Behaviour Change. Health Education \& Behaviour. 13(1): 73-92. doi 10.1177/109019818601300108

[65] Thau, S., Crossley, C., Bennett, R. J., \& Sczesny, S. 2007. The Relationship Between Trust, Attachment, and Antisocial Work Behaviors. Human Relations. 60: 1155-1179.

[66] Vardi, Y., \& Weitz, E. 2001. Lead Them Not Into Temptation: Job Autonomy as an Antecedent of Organizational Misbehavior.

[67] Walumbwa, F. O., Avolio, B. J., \& Zhu, W. 2008. How Transformational Leadership Weaves Its Influence on Individual Job Performance: The Role of Identification and Efficacy Beliefs. Personnel Psychology. 61 793-825. doi: 10.1111/j.1744-6570.2008.00131.x.

[68] Walumbwa, F. O., Lawler, J. J., Avolio, B. J., Peng, W., \& Kan, S. 2005. Transformational Leadership and Work-Related Attitudes: The Moderating Effects of Collective and Self-Efficacy Across Cultures. Journal of Leadership \& Organizational Studies. 11(3): 2-16. doi: 10.1177/107179190501100301.

[69] Wang, G., Dou, W., \& Zhou, N. 2012. The Interactive Effects of Sales Force Controls on Salespeople Behaviors and Customer Outcomes. Journal of Personal Selling and Sales Management. 32(2): 225-244. doi: 10.2753/PSS0885-3134320204.

[70] WBI. 2010. The United States Workplace Bullying Survey. United States: Workplace Bullying Institute.

[71] Zimmerman, B. J., Bandura, A., \& Martinez-Pons, M. 1992. SelfMotivation for Academic Attainment: The Role of Self-Efficacy Belief and Personal Goal Setting. American Educational Research Journal. 29: 663-676. doi: 10.3102/00028312029003663. 